\title{
In Vitro ADME, Preclinical Pharmacokinetics and Prediction of Human Pharmacokinetics of RBx14255, a Novel Ketolide with Pharmacodynamics Against Multidrug-Resistant Bacterial Pathogens
}

\author{
Tridib Chaira ${ }^{1,3,4}$, Tarani Kanta Barman ${ }^{2,3}$ and V. Samuel Raj ${ }^{2,3,4}$ \\ ${ }^{1}$ Department of Drug Metabolism and Pharmacokinetics and ${ }^{2}$ Department of Microbiology, Daiichi Sankyo India Pharma \\ Private Limited, Gurgaon, Haryana, India; ${ }^{3} \mathrm{New}$ Drug Discovery Research, Ranbaxy Research Laboratories, R \& D III, \\ Gurgaon, India; ${ }^{4}$ Centre for Drug Design Discovery and Development (C4D), SRM University, Delhi-NCR, Sonepat, \\ Haryana, India
}

Received, February 16, 2020; Revised, March 23, 2020 Accepted, April 20, 2020; Published, April 21, 2020.

\begin{abstract}
Purpose: The preclinical pharmacokinetic and pharmacodynamic properties of a potent fluoroketolide RBx14255 against Streptococcus pneumoniae and Haemophilus influenzae was compared with telithromycin and human clinical dose was predicted for preclinical development. Methods: The in vitro pharmacokinetic characterization was performed for solubility, Caco-2 permeability, microsomal stability, CYP inhibition and plasma protein binding. In vivo pharmacokinetic studies were performed in Swiss albino mice, Sprague Dawley rats and Beagle dogs. The pharmacodynamic studies were carried out in mouse against $S$. pneumoniae in systemic infection and against $S$. pneumoniae and $H$. influenzae in rat lung infection models. Results: RBx14255 showed superior potency and efficacy in mouse and rat infection models. RBx14255 showed $\mathrm{pH}$ dependent solubility $(0.41 \mathrm{mg} / \mathrm{mL}$ at $\mathrm{pH} 6.8$ and $>1 \mathrm{mg} / \mathrm{mL}$ at $\mathrm{pH} 1.2)$, moderate Caco-2 permeability (A to B: $12 \mathrm{~nm} / \mathrm{s})$ with high efflux ratio. It showed high plasma protein binding ( $>97 \%)$ in mouse and low binding (45$70 \%$ ) in rat, dog and human. The compound is mainly metabolized through CYP3A4. Pharmacokinetic parameters and absolute bioavailability of both, RBx14255 and telithromycin are similar in mouse. Both the ketolides showed low plasma clearance ( $18 \%$ of the normal hepatic blood flow rate) in mouse, moderate to high clearance in rat and dog. Mean oral bioavailability was high in mouse $(\geq 85 \%)$, moderate in rat (RBx14255: $15 \%$ and telithromycin: 51\%) and high to moderate in dog (RBx14255: 98\% and telithromycin: 56\%). The predicted efficacious dose for a $70 \mathrm{~kg}$ man ranges from $124 \mathrm{mg}$ BID to $226 \mathrm{mg}$ BID. Conclusion: RBx14255 displayed significantly better pharmacodynamics which correlates with the pharmacokinetic properties against $S$. pneumoniae and $H$. influenzae as compared to telithromycin. The predicted human efficacious doses are in the range of 124-226 mg, making it amenable to oral dosage form drug in human. This could be a promising clinical candidate for future studies.
\end{abstract}

\section{INTRODUCTION}

Pneumonia is an inflammatory condition of lung's parenchyma that is mostly, caused by infections. Many microorganisms such as bacteria, viruses, fungi, and parasites cause lung infection leading to pneumonia (1). Among these etiologies, bacterial pathogens are the major cause of mortality and morbidity. Bacterial pneumonia is classified as community-acquired pneumonia (CAP), hospitalacquired (HAP), healthcare-associated (HCAP) and ventilator-associated pneumonia (VAP). It is mainly caused by Streptococcus pneumoniae, Haemophilus influenzae, Staphylococcus aureus, Group A streptococci, Moraxella catarrhalis, anaerobes and aerobic Gram-negative bacteria $(2,3)$. Here we focus mostly on the infection caused by $S$. pneumoniae and $H$. influenzae. S. pneumoniae commonly known as pneumococcus is a highly invasive Gram-positive, extracellular bacterial pathogen is primarily responsible for CAP. Globally it is causing more deaths than any other infectious disease. Recent data estimate that $S$. pneumoniae is responsible for 14.5 million annual infections worldwide and $>800,000$ deaths in children $<5$ years of age $(4,7)$. Growing pneumococcal resistance to commonly prescribed antibiotics such as macrolides or cephalosporins and multidrug resistance (MDR) is serious public health concern (8). WHO has recently included this bacterium as one of the 12 top priority pathogens (9).

Corresponding Author: taranib@yahoo.com (Tarani), directorcd4@srmuniversity.ac.in (Samuel). 
Abbreviations: AUC, area under the concentration-time curve; BCRP, breast cancer resistant protein; BID, twice a day dosing; BW, body weight; Caco-2, human epithelial colorectal adenocarcinoma cells; CFU, colony forming unit; CYP, cytochrome P-450; $\mathrm{CL}_{\text {intr }}$, intrinsic clearance; CPCSEA, committee for the purpose of control and supervision of experiments on animals; ELF, epithelial lining fluid; F, oral bioavailability; HBSS, Hank's balanced salt solution; HEPES, 4-(2hydroxyethyl)-1-piperazineethanesulfonic acid; HTS, high throughput screening; $\mathrm{IC}_{50}$, concentration causing $50 \%$ inhibition; IV, intravenous; LC/MS/MS, liquid chromatography tandem mass spectrometry; n, number of replicates; MIC, minimum inhibitory concentration; NADPH, nicotinamide adenine dinucleotide phosphate; $\mathrm{P}_{\text {app }}$, apparent permeability; PBPK, physiologically based pharmacokinetic model; PK, pharmacokinetics; P-gp, P-glycoprotein; PO, per oral; $\mathrm{t}_{1 / 2}$, half-life; RTI, respiratory tract infection; SD, standard deviation; TEER, Transepithelial electrical resistance; UPLC, ultra-performance liquid chromatography; $\mathrm{UV}$, ultraviolet; $\mathrm{V}_{\mathrm{ss}}$, volume of distribution at steady state.

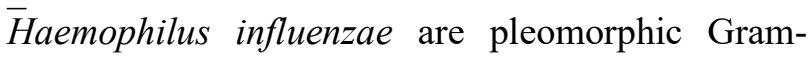
negative coccobacilli available in capsulated and non-capsulated forms. Capsulated invasive Heamophilus influenzae type b (Hib) is a common cause of pneumonia, epiglottitis, sepsis and other soft tissue infections and it was also the most common cause of meningitis in children below 5 years of age $(10,11)$.

Ketolides are a new class of semisynthetic antibiotic derived from the 14-membered macrolide, erythromycin A. Ketolides are designed to overcome resistance to macrolides with improved pharmacokinetic and pharmacodynamic properties of the existing macrolide compounds (12). Telithromycin, the first member of the ketolide family demonstrated high efficacy against $S$. pneumoniae isolates that cause community-acquired respiratory tract infection. It was approved in 2004 to treat simple and complicated upper and lower respiratory tract infections. Soon after approval, several severe adverse events became known, which included reversible visual disturbance, syncope,

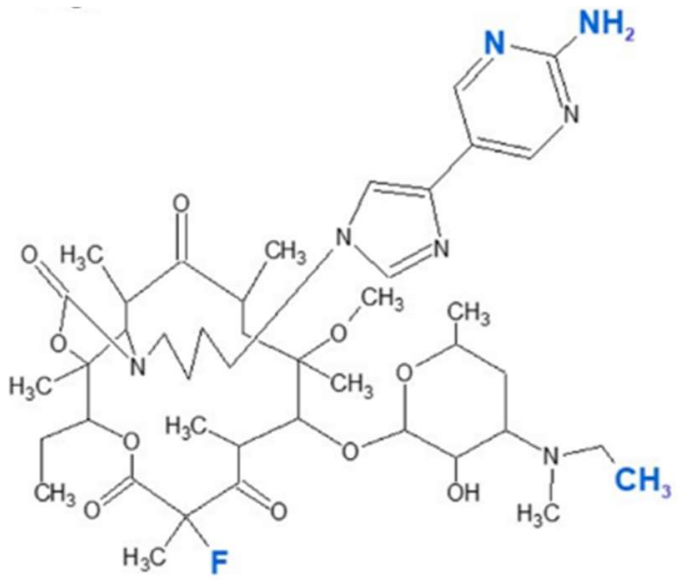

$\mathrm{RBx} 14255$ exacerbation of myasthenia gravis and hepatic failure (13, 14). The US Food and Drug Administration (FDA) withdrew its approval for safety concerns and allowed its use for communityacquired bacterial pneumonia, CAP (15-16). The emergence of telithromycin resistance in clinical isolates of S. pneumoniae was also reported (17-18). The continued search for newer ketolides by many pharmaceutical companies in recent time has reemphasized the importance of synthesis and evaluation of novel ketolides against MDR Gram positive bacteria (19-23). In this situation, investigation and further development of new ketolides require resolving the issues associated with telithromycin.

As part of the preclinical evaluation we have carried out here an extensive characterization of the in vitro and in vivo preclinical pharmacokinetic and pharmacodynamic properties of a novel fluoroketolide $\mathrm{RBx} 14255$ (Fig. 1) against $S$. pneumoniae and $H$. influenzae.

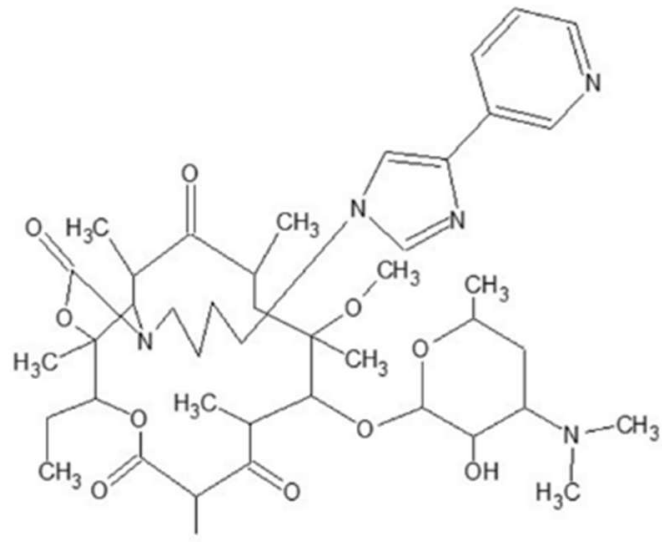

Telithromycin

Figure 1. Chemical structure of RBx14255 and telithromycin 


\section{MATERIALS AND METHODS}

\section{Chemicals}

RBx14255 was synthesized at Ranbaxy Research Laboratories, India. The Caco-2 cell line (human colon carcinoma epithelial cell line) was obtained from ATCC (HTB-37, Manassas, USA) and cells were used at passage number 36. Corning Transwell ${ }^{\circledR}$ filters 12-well, HBSS, HEPES, glucose and sodium bicarbonate were obtained from Sigma Aldrich (India). Liver microsomes and purified recombinant CYP450 isozymes, CYP1A2, CYP2C9, CYP2C19, CYP2D6 and CYP3A4 were purchased from BD Gentest (India). For the blood to plasma concentration ratio study, freshly collected mouse, rat and dog blood was obtained from in-house animals. Human blood was obtained from the Blood Bank (Gurgaon, India). For the protein binding study, a 96-well equilibrium dialyser with $150 \mu \mathrm{L}$ half-cell capacity (HTDialysis ${ }^{\circledR}$, Gales Ferry, USA) employing 12-14,000 Dalton molecular weight cutoff membranes was used. Standard substrates, metabolites, inhibitors, NADPH and deuterated analytical internal standards used for the CYP inhibition study were obtained from Sigma-Aldrich (Bangalore, India), BD Biosciences (Woburn, USA) and TRC (Toronto, Canada).

\section{Animal Husbandry and Ethical Approval}

Institutional Animal Ethics Committee (IAEC) of Daiichi Sankyo India Pharma Pvt. Ltd., Gurgaon, India approved all experimental protocols (mouse and rat) and IAEC of Ranbaxy Laboratories Limited, Gurgaon, India approved all experimental protocols (dog) for the use of animals. This study was conducted under the strict guidelines set out by the CPCSEA (Government of India) for the correct implementation of animal care and experimentation. Animals were acclimatized in study rooms for at least five days prior to dosing. The mouse and rat were housed in standard mouse and rat cages, respectively and maintained at $24 \pm 2^{\circ} \mathrm{C}$; controlled illumination was used to provide $12 \mathrm{~h}$ light/dark cycles. Dogs were housed in individual pens maintained in controlled environmental conditions $\left(22 \pm 3{ }^{\circ} \mathrm{C}\right.$; $40-70 \%$ Relative Humidity; 10-15 fresh air change cycles/h) with $12 \mathrm{~h}$ light and dark cycles. Standard pelleted diet (Golden Feeds, New Delhi, India) was given to mice and rats; dogs were given Pedigree ${ }^{\circledR}$ standard dog chow (manufactured by Effem India Private Limited, India) $300 \mathrm{~g}$ once a day. Water was allowed ad libitum throughout the study. Mice were fasted for $6 \mathrm{~h}$ and rats and dogs were fasted overnight before dosing and $2 \mathrm{~h}$ after dosing. Water was allowed throughout the study period. Good quality water passed through activated charcoal filter and exposed to UV rays was provided ad libitum throughout the study to all animals. In mice and rats, blood samples were collected through retro-orbital plexus using a sparse sampling design. In dogs, a serial sampling was carried out through cephalic vein.

\section{Physicochemical and In vitro Studies Solubility}

The solubility of RBx14255 was estimated at $\mathrm{pH} 1.2$ and 6.8. Test compound was prepared in DMSO was spiked into buffer $\mathrm{pH} 1.2$ (0.05 M sodium chloride, $\mathrm{pH}$ adjusted to 1.8 with hydrochloric acid) or phosphate buffer $\mathrm{pH} 6.8$ (0.05 M Sodium dihydrogen orthophosphate, adjusted to $\mathrm{pH} 6.8$ with sodium hydroxide) to potentially yield a final concentration of $1 \mathrm{mg} / \mathrm{mL}$ with $1 \%$ DMSO content. This solution was incubated at $25^{\circ} \mathrm{C}$ in a shaking water bath for 1 hour. The solution was filtered through membrane filter and analyzed in Acquity UPLC (Waters) using gradient mobile flow. Briefly, the mobile phase A was $0.05 \% \mathrm{v} / \mathrm{v}$ formic acid in a mixture of Milli-Q water and acetonitrile in the ratio of $95: 5$ and mobilie phase B was $0.05 \% \mathrm{v} / \mathrm{v}$ formic acid in acetonitrile. Chromatography was conducted on a Sunniest C18HT, (50x2.1) mm, $2.0 \mu \mathrm{m}$ (Chromanik, Japan) reverse phase column at a flow rate of $0.7 \mathrm{~mL} / \mathrm{min}$ using PDA detector with spectrum from 210-400 nm.

\section{Caco-2 permeability}

Permeability of RBx14255 (10 $\mu \mathrm{M})$ was determined in apical to basolateral (A-B) and basolateral to apical (B-A) directions. Transport studies were conducted 21 days post seeding in 12-well Transwell ${ }^{\circledR}$ inserts. Following pre-incubation in HBSS-HEPES buffer in an orbital shaker at $37^{\circ} \mathrm{C}$, $5 \% \mathrm{CO}_{2}$ for $30 \mathrm{~min}$, samples were withdrawn from the basolateral compartment at 15, 30, 45, 60, 90, and $120 \mathrm{~min}$, and from the donor chamber at 0 and $120 \mathrm{~min}$. At the end of the experiment, cells were washed with cold buffer and lysed with acetonitrile to assess cell accumulation and estimate the recovery. Cumulative amount ( $\mathrm{Q}$ in $\mu \mathrm{M})$ transported as a function of time was plotted and the slope of the linear segment was calculated, which is the linear appearance rate of the drug into the basolateral 
compartment (dQ/dt). Apparent permeability (Papp), was calculated using the equation

$$
\mathrm{P}_{\mathrm{app}}=\frac{\mathrm{dQ} / \mathrm{dt}}{\mathrm{A} \times \mathrm{C}_{0}}
$$

Where $\mathrm{dQ} / \mathrm{dt}$ is the slope of the line; $\mathrm{A}$ is the area of the cell monolayer $\left(4.2 \mathrm{~cm}^{2}\right.$ for a six well plate) and $\mathrm{C}_{0}$ is the initial concentration of the drug $(\mu \mathrm{M})$. The $\mathrm{P}_{\text {app }}$ value obtained is in $\mathrm{cm} / \mathrm{sec}$.

The ratio between Papp values in both transport studies (AB and $\mathrm{BA}$ ) was calculated according to the expression

$$
\mathrm{P}_{\mathrm{app}} \operatorname{ratio}(\mathrm{BA} / \mathrm{AB})=\frac{\mathrm{P}_{\mathrm{app}}(\mathrm{BA})}{\mathrm{P}_{\mathrm{app}}(\mathrm{AB})}
$$

\section{Microsomal stability}

Liver microsomes (concentration: $20 \mathrm{mg} / \mathrm{mL}$, Sekisui XenoTech) from males CD-1 mouse, Sprague-Dawley rat, Beagle dog, Cynomolgus monkey and mixed gender human (pool of 50 donors) were used for assays. $\operatorname{RBx} 14255(0.5 \mu \mathrm{M})$ and reference standard telithromycin were incubated in a reaction mixture consisting of liver microsomes and NADPH (reduced nicotinamide adenine dinucleotide phosphate) regenerating system. Aliquots were withdrawn at 3 min intervals until 30 min and were analyzed for parent compounds by LCMS/MS. The loss of parent was expressed as percentage of test compound remaining with time and the rate of decay was estimated by monoexponential decay kinetics. The rate of decay was normalized to microsomal protein per gram of liver and was expressed as $\mathrm{mL} / \mathrm{min} / \mathrm{g}$ liver.

\section{Reaction phenotyping}

RBx14255 and telithromycin were incubated (0.5 $\mu \mathrm{M})$ separately with five major CYP enzymes (recombinant CYP isozymes 1A2, 2C9, 2C19, 2D6 and $3 \mathrm{~A} 4$ at concentrations identical to HLM) and NADPH regenerating system. The relative extent of metabolism in all the matrices was compared following $30 \mathrm{~min}$ incubation.

\section{CYP inhibition}

CYP inhibition potential of the test compound and telithromycin was evaluated against five major CYP isozymes (1A2, 2C9, 2C19, 2D6 and 3A4) using
HTS inhibitor screening kit from BD Biosciences (Woburn, USA). Briefly, the test compound at various dilutions was incubated with a reaction mixture containing recombinant CYP enzyme, $\mathrm{NADPH}$ regenerating system and fluorogenic substrate. The formation of fluorescence was compared for the test groups with that of control reaction, performed in the absence of test compound. The percentage decrease in fluorescence in test group was expressed as a function of test compound concentration. The concentration of the test compound that reduces the metabolite formation by half $\left(1 \mathrm{C}_{50}\right)$ was calculated, using non-linear regression analysis.

\section{Plasma protein binding}

Plasma protein binding was evaluated in vitro using ultrafiltration technique. RBx14255 spiked in duplicates into plasma to produce $0.1 \mu \mathrm{g} / \mathrm{mL}$ and 1 $\mu \mathrm{g} / \mathrm{mL}(0.05 \% \mathrm{w} / \mathrm{v}$ DMSO) concentrations. After mixing, the samples were incubated for $30 \mathrm{~min}$ to ensure binding and centrifuged at $8000 \mathrm{~g}$ for $20 \mathrm{~min}$ using centricon (millipore $10 \mathrm{Kda}$ ) tubes to isolate the ultrafiltrate. The ultrafiltrate and retentate was collected and analyzed in LC-MS/MS to determine the concentrations of RBx14255. The test compound was estimated in the whole plasma samples and retentate and the fraction of compound bound to the plasma proteins was calculated.

Percentage plasma binding was calculated using the following equation

$$
\% \text { Bound to plasma }=\left[1-\frac{\mathrm{C}_{\mathrm{uf}}}{\mathrm{C}_{\mathrm{p}}}\right] \times 100
$$

Where $\mathrm{C}_{\mathrm{p}}$ and $\mathrm{C}_{\mathrm{uf}}$ denote the initial concentration of test compound in plasma and the concentration of test compound in ultra-filtrate, respectively.

\section{In vivo Pharmacokinetic Studies Formulations}

The intravenous and oral formulations were prepared in acetate buffer ( $\mathrm{pH}$ 4.5). The intravenous administration dose volume was $2 \mathrm{~mL} / \mathrm{kg}$ for mice and $1 \mathrm{~mL} / \mathrm{kg}$ for rats and dog. The oral dose volume was $10 \mathrm{~mL} / \mathrm{kg}$ for mice and rats and $5 \mathrm{~mL} / \mathrm{kg}$ for dogs. Formulations were administered within $30 \mathrm{~min}$ of preparation.

\section{Pharmacokinetic studies}

Studies were performed in healthy male Swiss albino mice (20-30 g), Sprague Dawley rats (200-250 g) 
and Beagle dogs $(10-13 \mathrm{~kg})$. Mice were fasted $6 \mathrm{~h}$ prior to dosing and food was provided $2 \mathrm{~h}$ post dose. Rats and dogs were fasted overnight and were provided food $2 \mathrm{~h}$ post dose. For intravenous bolus dose administration, mice and rats were dosed through the tail vein, and dogs through the saphenous vein with $15 \mathrm{~min}$ infusion. The oral dose was administered by gavage for all animals. A sparse sampling design was used in mice $(n=3$ per time point). Serial blood sampling was used for rats (parallel groups; $n=3$ ) and dogs (crossover; $n=3$ ). Blood samples were collected at 0.083 (only IV), $0.25,0.5,1,2,4,8$ and $24 \mathrm{~h}$ post-dose. Plasma was harvested from plasma following centrifugation $\left(3000 \mathrm{~g}, 5 \mathrm{~min}, 4^{\circ} \mathrm{C}\right)$ and stored at $-80^{\circ} \mathrm{C}$ until analysis.

\section{Pharmacokinetic analysis}

Pharmacokinetic parameters were calculated using non-compartmental analysis tool of validated Phoenix WinNonlin ${ }^{\circledR}$ software (Version 6.3). Parameters were calculated for individual concentration-time profiles where possible; otherwise the mean values were used. The area under the concentration time curve ( $\mathrm{AUC}_{\text {last }}$ and $\left.\mathrm{AUC}_{\text {inf }}\right)$ was calculated by linear trapezoidal rule. The elimination rate constant value $\left(\mathrm{k}_{\mathrm{el}}\right)$ was obtained by linear regression of the log-linear terminal phase of the concentration-time profile using at least 3 nonzero declining concentrations in terminal phase with a correlation coefficient of $>0.8$. The peak concentration $\left(\mathrm{C}_{\max }\right)$, time for the peak concentration $\left(t_{\max }\right)$, plasma clearance $\left(\mathrm{CL}_{\mathrm{p}}\right)$ and distribution volume at steady state $\left(\mathrm{V}_{\mathrm{ss}}\right)$ were the observed values. $\mathrm{F}_{\text {oral }}(\%)$ was calculated from the following equation

$$
\% \mathrm{~F}_{\text {oral }}=\frac{A U C_{P O} \times \text { Dose }_{I V}}{A U C_{I V} \times \text { Dose }_{P O}} \times 100
$$

Where $\mathrm{AUC}_{\mathrm{IV}}$ and $\mathrm{AUC}_{\mathrm{PO}}$ are $\mathrm{AUC}$ estimates after the intravenous and oral administration, respectively, and Dose ${ }_{I V}$ and Dose $\mathrm{PO}_{\mathrm{PO}}$ are the administered doses for intravenous and oral administration, respectively. Allometric methods were used to predict human blood clearance, volume of distribution and half-life $(24,25)$.

\section{Lung to plasma concentration ratio}

Lungs and blood from male Swiss Albino mouse and Sprague Dawley rat were collected and pooled $(n=3)$ at different time points till $24 \mathrm{~h}$ post dose following
$5 \mathrm{mg} / \mathrm{kg}$ oral or intravenous dose. Plasma was harvested from blood by centrifugation and pooled lungs were homogenized in ice-cold phosphate buffer ( $\mathrm{pH}$ 7.4). The plasma and lung homogenate were processed and analyzed for parent compound by LC-MS/MS. Area under the curve (AUC) were calculated using non-compartmental analysis in Phoenix WinNonlin ${ }^{\circledR}$ software (Version 6.3).

\section{Pharmacodynamic Study}

Efficacy of RBx14255 against S. pneumoniae 994 mef in murine systemic infection model

Swiss albino mice weighing 18-22 g of either sex were used for the study. Animals were acclimatized for 7 days to the experimental conditions prior to the start of experiments. In all treated as well as untreated control groups, six mice $(n=6)$ were taken per group. Overnight grown culture of $S$. pneumoniae 994 mef was suspended in sterile saline and the optical density was adjusted to $3.3 \mathrm{Mc}$ Farland; which was further diluted to 1:100. Equal volume of diluted culture was mixed with $10 \%$ hog mucin and $0.5 \mathrm{~mL}$ of inoculum containing $2.5 \times 10^{5}$ CFU was injected intra-peritoneally to each mouse. Treatment initiated $1 \mathrm{~h}$ post infection and was administered BID for 3 days. RBx14255 and telithromycin in the dose range $3.12,6.25,12.5,25$ and $50 \mathrm{mg} / \mathrm{kg} \mathrm{BW}$ and clarithromycin $25,50,100$ and $200 \mathrm{mg} / \mathrm{kg}$ and amoxicillin/clavulanic acid 6.25, $12.5,25$ and $50 \mathrm{mg} / \mathrm{kg}$ were administered twice daily orally. The mice were observed for 7 days and the survival of mice was recorded. $\mathrm{ED}_{50}(\mathrm{mg} / \mathrm{kg} \mathrm{BW})$ was calculated by Spearman Karber formula on day 7. Data are representative of two independent experiments.

Pharmacodynamics of RBx14255 against MA80 S. pneumoniae in rat lung infection model

Sprague Dawley rats $(90 \pm 20 \mathrm{~g})$ of either sex $(n=4)$ were used for this study. Rats were infected with 200 $\mu \mathrm{L}$ of MA80 S. pneumoniae suspended in $0.6 \%$ agar containing $10^{7} / \mathrm{mL} \mathrm{CFU} \mathrm{by} \mathrm{intratracheal} \mathrm{intubation.}$ $\mathrm{RBx} 14255$ were administered $30 \mathrm{mg} / \mathrm{kg}$ single dose by oral route. Blood collection was done (4 rats/time point) at $15 \mathrm{~min}, 30 \mathrm{~min}, 1 \mathrm{~h}, 2 \mathrm{~h}, 4 \mathrm{~h}, 6 \mathrm{~h}, 8 \mathrm{~h}, 12 \mathrm{~h}$ and $24 \mathrm{~h}$, after the dose. Sodium citrate $(20 \% \mathrm{w} / \mathrm{v})$ was used as an anticoagulant. Plasma separation was done by centrifugation at $3,000 \mathrm{~g}$ for $5 \mathrm{~min}$. at $4^{\circ} \mathrm{C}$. Lungs were excised from the sacrificed rats at 30 min, $2 \mathrm{~h}, 4 \mathrm{~h}, 6 \mathrm{~h}, 8 \mathrm{~h}, 12 \mathrm{~h}$ and $24 \mathrm{~h}$. The lung weights were recorded and $\mathrm{K}_{2} \mathrm{HPO}_{4}-\mathrm{KH}_{2} \mathrm{PO}_{4}$ phosphate 
buffer (pH 7.4) added to the lungs ( $2 \mathrm{~mL} / \mathrm{g}$ of lung) and homogenized in ice-cold condition. Final volume of the lung homogenates was recorded. An aliquot of lung homogenate, of all time points were serially diluted and spotted on agar plates to determine the lung bacterial load reduction. Plasma and lung homogenates were stored at $-80^{\circ} \mathrm{C}$. The concentration of RBx14255 in plasma was analyzed by LC-MS/MS.

\section{Pharmacodynamics of RBx14255 against $H$. influenzae in rat lung infection model}

Sprague Dawley rats (70-90 g, $\mathrm{n}=6)$ were infected with $200 \mu \mathrm{L}$ of $H$. influenzae LA85021 suspended in $0.6 \%$ agar containing $10^{7} / \mathrm{mL} \mathrm{CFU}$ by intratracheal intubation. Single dose of RBx14255 (100 mg/kg) was administered by subcutaneous route $2 \mathrm{~h}$ postinfection. Plasma, bronchoalveolar lavage (BAL), and lung tissue were sampled at $0.5 \mathrm{~h}, 1 \mathrm{~h}, 2 \mathrm{~h}, 5 \mathrm{~h}$, $8 \mathrm{~h}$ and $24 \mathrm{~h}$ post infection. The blood samples were centrifuged at $10,000 \mathrm{rpm}$ for $5 \mathrm{~min}$. at $4^{\circ} \mathrm{C}$. Plasma was separated and stored at $-80^{\circ} \mathrm{C}$. Immediately after blood collection, BAL fluid was aspirated by infusion of $2.5 \mathrm{~mL}$ of physiological saline $(\mathrm{pH} 7.2 \pm$ 0.2 ), flushed two times in the lungs of each rat. The BAL samples were immediately centrifuged at $400 \mathrm{xg}$ for $10 \mathrm{~min}$ at $4^{\circ} \mathrm{C}$ and the supernatants were collected and stored at $-80^{\circ} \mathrm{C}$ until analyzed. After BAL sampling, the lungs were excised, collected in saline, homogenized and stored at $-80^{\circ} \mathrm{C}$. An aliquot of lung homogenate was used to assess bacterial load in lungs by serial dilution plating at all the time points. Concentrations of RBx14255 in plasma, ELF and lung homogenates were determined by bioaasaybased method using B. subtilis ATCC 6633. The drug concentration in ELF was calculated using urea as a marker of dilution. The following equation as described by Muller-Serieys et al. (1986) was used.

$$
[\text { Drug }]_{\mathrm{ELF}}=[\text { Drug }]_{\mathrm{BAL}} \times\left\{\frac{[\text { Urea }]_{\mathrm{PLASMA}}}{\left[\text { Urea }_{\mathrm{BAL}}\right.}\right\}(5)
$$

The average urea factor for plasma/BAL for Sprague Dawley rat was estimated to be 14 . This factor was used for drug estimation in ELF.

\section{Pharmacokinetic-Pharmacodynamic Analysis Species-invariant time method (complex Dedrick plots)}

The general idea behind the species-invariant time method originates from the allometric approach, and the prediction performance depends on the allometric relationships of the pharmacokinetic parameters across species. The species-invariant time method is based on the assumption that by normalizing the concentrations by body weights and transforming the chronological time to the physiological time, which is defined by the number of heartbeats or the number of respirations an animal will have in its lifespan, the plasma concentrationtime curves should be superimposable in all species. Dedrick first transformed chronological time to the equivalent time (26) and Boxenbaum (26) later introduced new units of pharmacokinetic time: kallynochrons, apolysichrons, and dienetichrons. In the Dedrick plot using equivalent time, the intravenous free plasma concentration-time curve was transformed by dividing the concentrations and time scales of various species by dose (per kilogram of body weight) or $W^{0.25}$, respectively. In the Dedrick plot using kallynochrons, apolysichrons, and dienetichrons as time units, $b, c$, and $d$ are the allometric scaling exponents of $\mathrm{CL}, \mathrm{Vd}_{\mathrm{ss}}$, and $\mathrm{CL} \times \mathrm{MLP}$ (maximum life-span potential), respectively (27). The transformed concentrationtime curves of various species are superimposed and then back-transformed to estimate human i.v. plasma concentration-time profiles. The predicted human i.v. profile, in combination with the estimated mean absorption rate constants and bioavailability, was then used to simulate the oral pharmacokinetic profile in humans. Mahmood and Yuan (27) compared the accuracies of transformations via equivalent time, kallynochrons, and apolysichrons for predicting human $\mathrm{CL}, \mathrm{Vd}_{\mathrm{ss}}$, and $\mathrm{t}_{1 / 2}$. They observed that equivalent time was inferior to kallynochrons and apolysichrons, which might be due to the fixed exponent of 0.25 . Since the correction factors for Dedrick plot transformations were derived from allometric scaling exponents, it is not surprising that they observed comparable prediction accuracy between allometric scaling and Dedrick plots. The derived complex Dedrick equations are as follows:

$$
C_{p}=\frac{D}{V} \times e^{-\frac{C L}{V} t}
$$




$$
\begin{aligned}
& \Rightarrow \frac{C_{p}}{D / W}=\frac{1}{C \cdot W^{c} / W} \times e^{-\frac{B \cdot W^{b}}{C \cdot W^{c}} \times t} \quad\left(C L=B \cdot W^{b}, V=C \cdot W^{c}\right) \\
& \Rightarrow \frac{C_{p}}{D / W^{c}}=\frac{1}{C} \times e^{-\frac{B}{C} \times t^{\prime}} \quad\left(\because t^{\prime}=W^{b-c} \cdot t\right) \quad \text { [complex Dedrick plot] } \\
& \text { Concentration scale }=\frac{C_{p}}{D / W^{c}} \text { and Time scale }=W^{b-c} \cdot t
\end{aligned}
$$

\section{RESULTS}

\section{Physicochemical Properties and In vitro Studies Solubility, permeability and plasma protein binding}

Mean solubility of RBx 14255 and telithromycin of 6 samples is 0.41 and $0.34 \mathrm{mg} / \mathrm{mL}$ at $\mathrm{pH} 6.8$, and $>1$ $\mathrm{mg} / \mathrm{mL}$ at $\mathrm{pH} 1.2$. RBx14255 and telithromycin exhibited moderate A to B permeability across the Caco-2 monolayer $(12 \mathrm{~nm} / \mathrm{s}$ and $16 \mathrm{~nm} / \mathrm{s}$, respectively) at same molar concentration and experimental condition. RBx14255 showed 3-fold lower efflux ratio compared to telithromycin. The efflux ratio greater than 2 indicating that the compounds are substrates for the efflux transporters (28) P-gp and BCRP (Table 1).

Table 1. Trans-epithelial transport of RBx14255 and telithromycin across Caco-2 Monolayer

\begin{tabular}{lccc}
\hline Compound & $\begin{array}{c}P_{\text {app }} \text { A to B } \\
(\mathrm{nm} / \mathrm{s})\end{array}$ & $\begin{array}{c}P_{\text {app }} \text { B to A } \\
(\mathrm{nm} / \mathrm{s})\end{array}$ & $\begin{array}{c}\text { Efflux ratio } \\
{\left[\mathrm{P}_{\text {app }} \text { ratio }\right.} \\
(\mathrm{BA} / \mathrm{AB})]\end{array}$ \\
RBx14255 & $12 \pm 1.2$ & $22 \pm 1.6$ & 1.8 \\
Telithromycin & $16 \pm 2.1$ & $79 \pm 5.8$ & 4.9 \\
\hline
\end{tabular}

Data is presented as mean value \pm standard deviation from three replicates. Papp is the apparent permeability in Caco-2 cell assayfrom apical-to-basolateral (AB) and basolateral-to-apical (BA) side at $\mathrm{pH}=7.4$.

RBx14255 and telithromycin showed high binding $(>97 \%)$ in mouse plasma whereas plasma protein binding in other species (rat, dog and human) studied was low (34.44\% to $69.6 \%$ ) at both the concentrations studied. $\mathrm{RBx} 14255$ was found to be highly bound to plasma proteins in lower animals compared to higher animals which showed low protein bound. These results were consistent with telithromycin values.

The oral absorption properties of RBx 14255 were superior compared to telithromycin. The compound showed $\mathrm{pH}$ dependent solubility 0.41 $\mathrm{mg} / \mathrm{mL}$ at $\mathrm{pH} 6.8$ and $>1 \mathrm{mg} / \mathrm{mL}$ at $\mathrm{pH} 1.2$ and a moderate permeability (12 nm/s in Caco-2 cells) similar to telithromycin. In contrast to moderate oral bioavailability of telithromycin at low oral doses in three rodent species (50-60\%), RBx14255 showed excellent bioavailability (70-100\%) consistent with its better permeability compared to telithromycin.

\section{Metabolic stability and reaction phenotyping}

The in vitro microsomal $\mathrm{CL}_{\text {intr }}$ of $\mathrm{RBx} 14255$ and telithromycin showed high metabolic stability in liver microsomes from mouse, rat, dog and human ( 0.7 to $3.0 \mathrm{~mL} / \mathrm{min} / \mathrm{g}$ liver). Monkey showed high $\mathrm{CL}_{\text {intr }}$ which is consistent with telithromycin (Table 2). The in vivo clearance is consistent with in vitro hepatic microsomal clearance which suggests that liver is likely to be the main excretory organ for both $\mathrm{RBx} 14255$ and telithromycin except for telithromycin clearance in dog which is high, could be due to contribution of other organs. The high oral bioavailability of RBx14255 in rodents and nonrodent compared to moderate bioavailability in telithromycin is consistent with the intestinal efflux values which is about $44 \%$ lower than telithromycin.

Reaction phenotyping study of both RBx 14255 and telithromycin showed minimal metabolism (0$13 \%$ ) in four CYP isozyme namely CYP1A2, 2C9, 2C19 and 2D6. Whereas, through CYP3A4, the metabolism of telithromycin and RBx14255 metabolized was $88 \%$ and $93 \%$, respectively. Reaction phenotyping results suggests that high metabolic clearance of RBx14255 and telithromycin is likely through CYP3A4 isozyme.

\section{CYP inhibition}

RBx14255 and telithromycin did not inhibit CYP1A2, CYP2C9 and CYP2C19 at concentrations up to $100 \mathrm{Mm}$ (triplicate IC50 studies). Compared to RBx14255, telithromycin moderately inhibit CYP2D6. However, RBx14255 and telithromycin inhibit CYP3A4 with an IC50 value of $1.5 \pm 0.6 \mathrm{Mm}$ and $1.4 \pm 0.7 \mathrm{Mm}$, respectively. 
Table 2: Metabolic stability of RBx14255 and telithromycin in liver microsomes

\begin{tabular}{lcc}
\hline \multirow{2}{*}{ Matrix } & \multicolumn{2}{c}{$\mathrm{CL}_{\text {intr }}(\mathrm{mL} / \mathrm{min} / \mathrm{g}$ liver $)$} \\
\cline { 2 - 3 } Mouse & $2.4 \pm 0.2$ & $0.7 \pm 0.1$ \\
Rat & $0.6 \pm 0.04$ & $0.8 \pm 0.07$ \\
Dog & $1.6 \pm 0.1$ & $1.0 \pm 0.1$ \\
Monkey & $>8$ & $>8$ \\
Human & $1.8 \pm 0.2$ & $3.0 \pm 0.4$ \\
\hline
\end{tabular}

Note: 0-3: low, 3-8: moderate, $>8$ : high clearance

\section{Pharmacokinetics}

RBx14255 and telithromycin had close pharmacokinetic properties including bioavailability in mouse. Both ketolides showed low plasma clearance $(18 \%$ of the normal hepatic blood flow rate) in mouse with half-life ranges from 1.0 to $1.6 \mathrm{~h}$. They were well distributed with a steady state distribution volume of 1.5 to 2.2 times the total body water and showed high mean oral bioavailability of $\geq 85 \%$ (Table 3 ). In the rat, they showed moderate to high blood clearance $(52 \%$ and $90 \%$ of the normal hepatic blood flow rate for RBx14255 and telithromycin, respectively), well distributed with total steady state distribution volume of $>4$ times the total body water. The compounds showed a half-life of $\sim 3 \mathrm{~h}$ with moderate oral bioavailability (RBx14255: 70\% and telithromycin: 51\%). In dog, compounds showed moderate to high blood clearance $(58 \%$ and $85 \%$ of the normal hepatic blood flow rate for $\mathrm{RBx} 14255$ and telithromycin, respectively) with high volume of distribution ( $>4$ times the total blood volume). RBx14255 showed a long half-life of $18 \mathrm{~h}$, about 7-fold higher than telithromycin. Oral bioavailability of RBx 14255 was $98 \%$ almost double that of telithromycin. The pharmacokinetic properties of RBx14255 suggest that it has the potential to be administered as low BID dose. The high volume of distribution in all preclinical species is, in part, due to high distribution in lungs as observed in rat. Its moderately long halflife in vivo in the various animal species $\left(\mathrm{t}^{1} 1 / 2=1.57 \mathrm{~h}\right.$ in the mouse, $2.63 \mathrm{~h}$ in rat and $17 \mathrm{~h}$ in dog), result from a combination of a relatively low clearance and a high volume of distribution.

\section{Lung to Plasma Ratio}

The partitioning of test compounds into lungs from partitioninginto lungs was 7 to 16 -fold higher than plasma. However, the lung to plasma exposure pattern of RBx 14255 and telithromycin in mouse and rat following oral and intravenous dose was found to be similar as shown in Table 4.

\section{Pharmacodynamic}

Efficacy of RBx14255 against S. pneumoniae 994 mef in murine systemic infection

The $\mathrm{ED}_{50}(\mathrm{mg} / \mathrm{kg} \mathrm{BW})$ of RBx14255, telithromycin, amoxicillin/clavulanic acid and clarithromycin (Table 5) against S. pneumoniae 994 mef murine systemic infection were found to be $13.81,15.72$, 15.78 and $141 \mathrm{mg} / \mathrm{kg}$ body weight indicating its superior potency as compared to clarithromycin and equivalent to other commercially available standard drugs.

\section{Pharmacodynamics of RBx14255 against MA80 S. pneumoniae in rat lung infection model}

The pharmacodynamic and pharmacokinetic parameters are presented in Fig. 2 and Table 6, respectively. $\mathrm{RBx} 14255$ showed bactericidal potential starting $8 \mathrm{~h}$ post infection with bacterial log reduction being $4.417 \log _{10}$. This for telithromycin was $3.32 \log _{10}$. Thus, RBx14255 was equipotent to telithromycin with $1 / 4$ th exposure levels in the plasma in Sprague Dawley rats.

\section{Pharmacodynamics of RBx14255 against $H$. influenzae in rat lung infection model}

The histograms in Fig. 3 depict the $\log \mathrm{CFU} / \mathrm{mL}$ of bacteria, which decreased to $4.25 \log _{10}$ at $5 \mathrm{~h}$ and $2.24 \log _{10}$ in $8 \mathrm{~h}$ indicating a significant load reduction compared to the untreated control. The drug levels at $5 \mathrm{~h}$ were $1.41,2.03$ and $7.69 \mu \mathrm{g} / \mathrm{mL}$ in plasma, ELF and lung tissue, respectively.

The $H$. influenzae load reduction was observed as early as $1 \mathrm{~h}$ and bactericidal effect $\left(\geq 3 \log _{10}\right.$ $\mathrm{CFU} / \mathrm{mL}$ reduction from the initial inoculum, i.e., $6.4 \log _{10}$ ) was achieved at $8 \mathrm{~h}$. Significant eradication $\left(\geq 4 \log _{10} \mathrm{CFU} / \mathrm{mL}\right.$ reduction from the initial inoculum) was observed at $24 \mathrm{~h}$. The pharmacodynamic parameter associated with bacterial inhibition correlated well with the achieved levels of RBx14255 in the epithelial lining fluid and lung tissue. The concentrations in the three compartments are in the order plasma $<\mathrm{ELF}<$ lung. The peak concentrations of RBx14255 in the ELF and lung were achieved in 1-2 $\mathrm{h}$ and remain above MIC till $8 \mathrm{~h}$, which resulted in increased bacterial eradication. 
Table 3. In vivo pharmacokinetic parameter estimates of $\mathrm{RBx} 14255$ and telithromycin

\begin{tabular}{|c|c|c|c|c|c|c|c|c|c|}
\hline Compound & Species & $\begin{array}{c}\text { Dose } \\
(\mathrm{mg} / \mathrm{kg})\end{array}$ & Route & $\begin{array}{l}T_{\max } \\
\text { (h) }\end{array}$ & $\begin{array}{c}\mathrm{AUC}_{\text {last }} \\
(\mu \mathrm{g} / \mathrm{h} / \mathrm{Ml})\end{array}$ & $\begin{array}{c}\mathrm{CL}_{\text {blood }} \\
(\mathrm{Ml} / \mathrm{min} / \mathrm{kg})\end{array}$ & $\begin{array}{l}V_{\text {ss,blood }} \\
(\mathrm{L} / \mathrm{kg})\end{array}$ & $\begin{array}{l}t_{1 / 2} \\
\text { (h) }\end{array}$ & $\begin{array}{c}\text { F } \\
(\%)\end{array}$ \\
\hline \multirow{6}{*}{$\mathrm{RBx} 14255$} & \multirow{2}{*}{ Mouse } & 5 & IV & & 5.24 & 15.9 & 1.10 & 1.57 & \multirow[b]{2}{*}{85} \\
\hline & & 25 & $\mathrm{PO}$ & 2.00 & 22.22 & & & & \\
\hline & \multirow{2}{*}{ Rat } & 5 & IV & & $2.80 \pm 0.59$ & $31.23 \pm 5.77$ & $2.74 \pm 1.12$ & $2.63 \pm 1.45$ & \multirow[b]{2}{*}{70} \\
\hline & & 25 & $\mathrm{PO}$ & $2.10 \pm 1.62$ & $9.74 \pm 0.87$ & & & & \\
\hline & \multirow[b]{2}{*}{ Dog } & 3 & IV & & $3.02 \pm 1.10$ & $18.05 \pm 5.81$ & $3.88 \pm 0.84$ & $17.95 \pm 5.81$ & \multirow[b]{2}{*}{98} \\
\hline & & 15 & $\mathrm{PO}$ & $2.33 \pm 1.15$ & $14.79 \pm 5.94$ & & & & \\
\hline \multirow{6}{*}{ Telithromycin } & \multirow{2}{*}{ Mouse } & 5 & IV & & 5.15 & 16.22 & 1.56 & 1.12 & \multirow[b]{2}{*}{55} \\
\hline & & 25 & $\mathrm{PO}$ & 2.00 & 14.11 & & & & \\
\hline & \multirow{2}{*}{ Rat } & 5 & IV & & $1.90 \pm 0.76$ & $49.02 \pm 15.84$ & $6.04 \pm 2.62$ & $2.91 \pm 1.73$ & \multirow[b]{2}{*}{51} \\
\hline & & 25 & $\mathrm{PO}$ & $2.70 \pm 0.63$ & $4.83 \pm 1.30$ & & & & \\
\hline & \multirow{2}{*}{ Dog } & 5 & IV & & $1.90 \pm 0.29$ & $26.48 \pm 3.72$ & $3.17 \pm 0.83$ & $2.62 \pm 0.89$ & \multirow[b]{2}{*}{56} \\
\hline & & 15 & $\mathrm{PO}$ & $0.83 \pm 0.33$ & $5.26 \pm 0.93$ & & & & \\
\hline
\end{tabular}

Table 4. Lung to plasma exposure ratio in male Swiss albino mouse and Sprague Dawley rat $(n=3)$

\begin{tabular}{|c|c|c|c|c|}
\hline \multirow{3}{*}{ Compound } & \multicolumn{4}{|c|}{$\mathrm{AUC}_{0-\infty}$ ratio (Lung/Plasma) } \\
\hline & \multicolumn{2}{|c|}{ Mouse $(5 \mathrm{mg} / \mathrm{kg})$} & \multicolumn{2}{|c|}{ Rat $(5 \mathrm{mg} / \mathrm{kg})$} \\
\hline & PO & IV & $\mathrm{PO}$ & IV \\
\hline $\mathrm{RBx} 14255$ & $0.44 \pm 0.21$ & $1.21 \pm 0.43$ & $7.04 \pm 2.41$ & $15.8 \pm 3.03$ \\
\hline Telithromycin & $0.38 \pm 0.15$ & $1.17 \pm 0.61$ & $10.33 \pm 4.62$ & $12.22 \pm 5.18$ \\
\hline
\end{tabular}

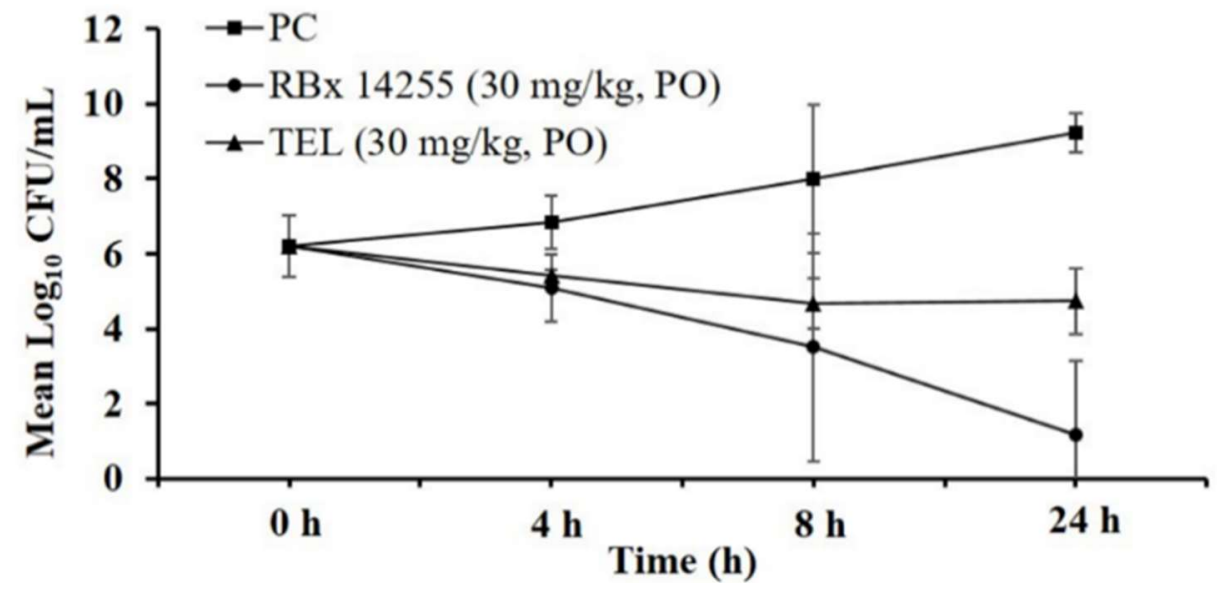

Figure 2. Bacterial load in lungs of RBx14255 and telithromycin treated animals at different time points as compared to untreated control (PC) 
Table 5. $\mathrm{ED}_{50}(\mathrm{mg} / \mathrm{kg} \mathrm{BW})$ of $\mathrm{RBx} 14255$ as compared to telithromycin against $S$. pneumoniae 994 mef murine systemic infection model

\begin{tabular}{|c|c|c|}
\hline \multicolumn{3}{|c|}{ S. pneumoniae 994 mef systemic infection } \\
\hline Compound & $\begin{array}{c}\mathrm{ED}_{50} \\
\mathrm{mg} / \mathrm{kg} \mathrm{BW} *\end{array}$ & $\begin{array}{c}\text { Confidence } \\
\text { Interval }\end{array}$ \\
\hline $\mathrm{RBx} 14255$ & 13.81 & $10.34,37.93$ \\
\hline Telithromycin & 15.72 & $10.74,23.01$ \\
\hline $\begin{array}{l}\text { Amoxicillin/ } \\
\text { Clavulanic acid }\end{array}$ & 15.78 & $8.14,30.58$ \\
\hline Clarithromycin & 141 & $10.97,>200$ \\
\hline
\end{tabular}

*Number of mice, $\mathrm{n}=6$ per group/experiment

Table 6. Comparative PK parameters of RBx 14255 and telithromycin in Sprague Dawley rats after single oral dose $(30 \mathrm{mg} / \mathrm{kg})$

\begin{tabular}{lcccc}
\hline Compound & $\begin{array}{c}\mathrm{t}_{\max } \\
\mathrm{h}\end{array}$ & $\begin{array}{c}\mathrm{C}_{\max } \\
\mathrm{ng} / \mathrm{mL}\end{array}$ & $\begin{array}{c}\mathrm{AUC} \text { inf } \\
\mathrm{ng} . \mathrm{h} / \mathrm{mL}\end{array}$ & $\begin{array}{c}\mathrm{t}_{1 / 2} \\
\mathrm{~h}\end{array}$ \\
RBx14255 & 6.0 & 149.5 & 934.2 & 4.56 \\
Telithromycin & 4.0 & 860.5 & 3811.6 & 3.05 \\
\hline
\end{tabular}

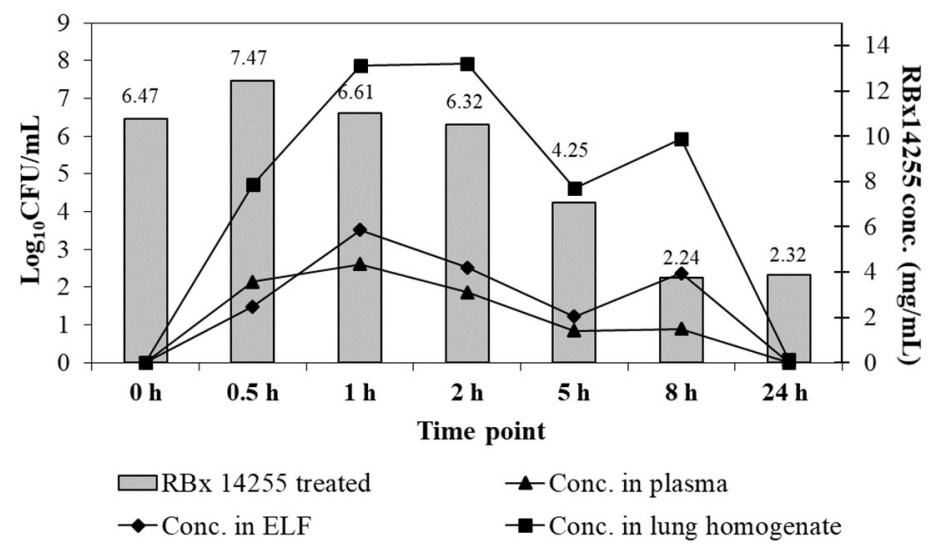

Figure 3. RBx14255 levels in plasma, ELF and lung tissue vs. bacterial load in lungs of RBx14255 treated animals.

The data labels above the bars indicate the $\log _{10} \mathrm{CFU} / \mathrm{mL}$ in the RBx14255 treated animals.RBx14255 exhibited accumulation in lung tissue much above its MIC levels $(2 \mu \mathrm{g} / \mathrm{mL})$ upto $8 \mathrm{~h}$. The concentrations of RBx14255 in the lung tissue and epithelial lining fluid were more than the corresponding plasma levels at all time points. The pharmacodynamic parameter associated with bacterial inhibition correlated well with the achieved levels of
RBx14255 in the epithelial lining fluid and lung tissue. The efficacy of any drug is dependent upon its transport and penetration to the target site of infection. For drugs of the RTI pathogens, high bronchopulmonary concentrations can be a key predictor of clinical outcome.

\section{Human PK Prediction and PK/PD Prediction of human PK and human efficacious doses}

The preclinical PK parameters were determined using model-independent pharmacokinetic calculations. First, simple allometric scaling of the clearance and volume of distribution data was performed using $Y=a W^{b}$, where $Y$ is the parameter of interest, and $a$ and $b$ are coefficient and exponent of the allometric equation, respectively, and $W$ is body weight $(25,29)$. The Rule of Exponents (RoE) method was used to improve the prediction of human clearance. Maximum lifespan potential (MLP) approach was used (30) because clearance exponent calculated using simple allometry exceeded 0.71 and less than 1.0 (Fig. 4). The plasma clearance and volume of distribution was estimated to be $6.26 \mathrm{~mL} / \mathrm{min} / \mathrm{kg}$ and $5.16 \mathrm{~L} / \mathrm{kg}$, respectively for $70 \mathrm{~kg}$ human. These human clearance and volume estimates gave an estimated blood half-life $\left(t_{1 / 2}=0.693 \times V_{\mathrm{ss}} / \mathrm{CL}\right)$ of $9.5 \mathrm{~h}$ for $\mathrm{RBx} 14255$ in humans, suggesting that the compound is likely to be a twice-a-day drug.

The high volume of distribution predicted in human is likely to show clinical relevance in lung distribution of RBx 14255 as observed in rodents and non-rodents. The predicted human efficacious dose range of 124-226 mg for RBx14255 makes it amenable to further oral dosage form study design in humans.

\section{Prediction of human plasma concentration - time profiles}

When predicting the first-in-human dosing, special attention is paid to the AUC after oral dosing, elimination half-life, and peak-to-trough plasma concentration ratio. This is because an estimate of exposure (AUC) is required to ensure efficacy and safety. Accurate assessment of the drug's maximum concentration $\left(C_{\max }\right)$ and trough concentration $\left(C_{\min }\right)$ is useful to avoid unwanted toxicity and maintain efficacious concentrations. Hence, early prediction of the concentration-time profiles for humans is of great importance. Currently, several methods have already been used to predict concentration-time profiles in humans based on preclinical data, such as 
the species-invariant time method (Dedrick plots), the $C_{\mathrm{ss}}-$ mean residence time (MRT) method, and the PBPK model.

\section{Clearance}

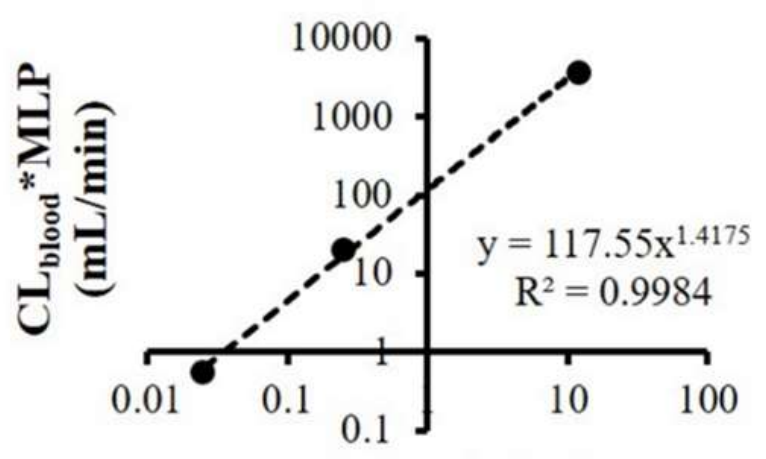

Body wt. (kg)

\section{Volume of Distribution}

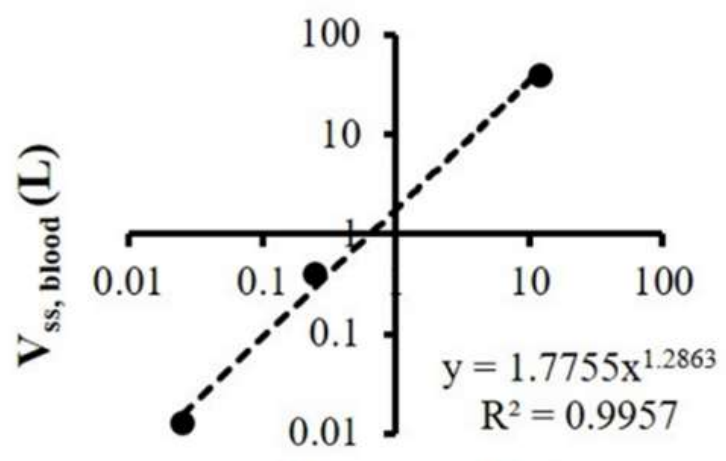

Body wt. (kg)

Figure 4. Allometric scaling of blood clearance and steady-state volume of distribution using pharmacokinetic data from preclinical species

\section{Species-invariant time method (complex Dedrick plots)}

To predict human efficacious oral doses, human plasma concentration time profiles (Fig. 5) were predicted from intravenous Dedrick plots incorporating of $\operatorname{dog} \mathrm{k}_{\mathrm{a}}$ (absorption constant) of 2.27 $\mathrm{h}^{-1}$, human plasma protein binding and $80 \%$ human oral bioavailability (mean oral bioavailability of three preclinical species). The following assumptions were made: (i) Human $k_{a}$ and dog $k_{a}$ are similar (ii) exposures in healthy animals are similar to those in the disease models, (iii) human bioavailability will be about $80 \%$. Based on the above assumptions, the minimum efficacious dose predicted for a $70 \mathrm{~kg}$ human ranges from $124 \mathrm{mg}$ BID to 226 mg BID (Fig. 6).

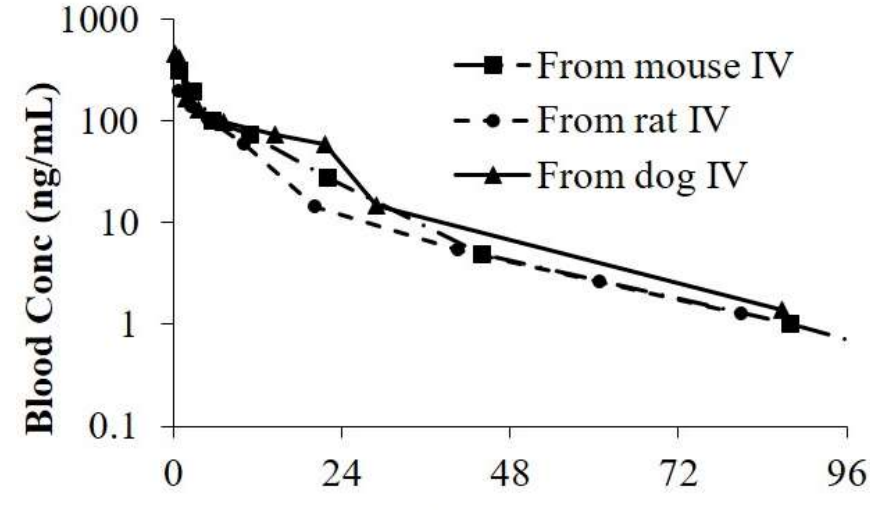

Time (h)

Figure 5. Complex Dedrick plots showing predicted human blood profiles from different preclinical species.

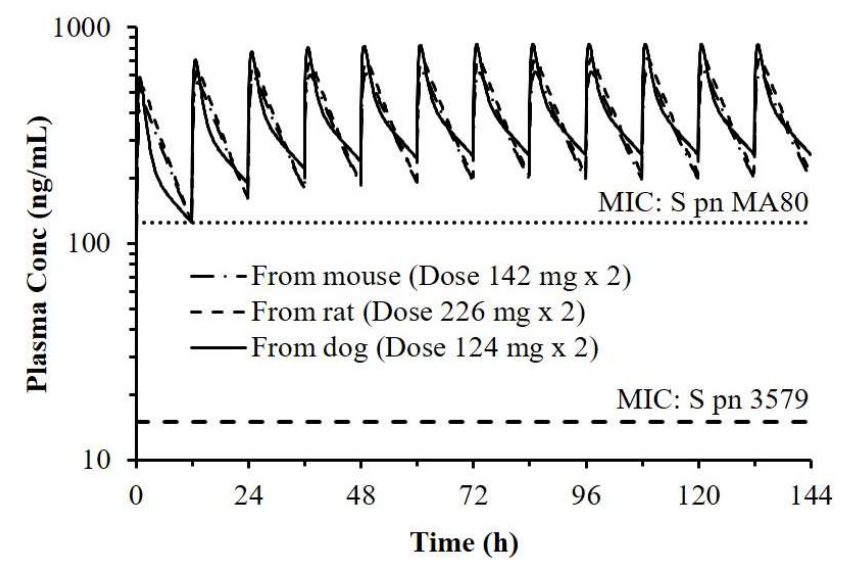

Figure 6. Predicted human oral plasma concentration time profiles above MIC derived from different preclinical species. The profiles were drawn considering $80 \%$ human oral bioavailability (mean oral bioavailability of three preclinical species) 


\section{DISCUSSION}

Bacterial pneumonia is the most widespread infection leading to hospitalization and mortality in all populations, especially the elderly and children $(31,32)$. The economic burden of pneumonia is significant, with annual expenses over $\$ 17$ billion in the United States and $€ 10$ billion in Europe (31, 33, 34). The increased rates of resistance against highly prevalent pathogens viz. Streptococcus pneumoniae and Haemophilus influenzae to commonly used antibiotics such as to beta-lactams, macrolides, and tetracyclines emphasize the necessity for new antibiotic agents $(35,36)$. RBx14255 (Fig. 1) is a newly identified potent a fluoroketolide for bacterial pneumonia being evaluated in preclinical development $(5,37,38)$. In the scenario of endless cycle of antibiotic resistance and growing need of new antibiotic, RBx14255 may represent a major advance for unmet medical need.

The studies described here show that RBx14255 possesses excellent preclinical in vitro and in vivo pharmacokinetic and pharmacodynamic properties. The main superiority of RBx14255 against telithromycin are (i) low intestinal efflux ratio (efflux ratio $<2$ and 3 -fold lower than telithromycin), (ii) high metabolic stability in human liver microsomes, (iii) low to moderate plasma clearance (iv) high oral bioavailability across rodents (mouse and rat) and non-rodents (dog) and (v) excellent pharmacodynamic properties compared to telithromycin in different animal models. The advantage of low intestinal efflux ratio of RBx 14255 is likely to be the main reason for overall high oral bioavailability across rodents and non-rodents. Allometric scaling of animal data predicts that the compound will have good pharmacokinetic properties in humans with moderately long half-life, low plasma clearance and high volume of distribution. The human oral plasma profiles generated from complex Dedrick plots predicts requirement of low efficacious dose for the treatment of $H$. influenzae against targeted pathogens.

The in vitro microsomal $\mathrm{CL}_{\text {intr }}$ of $\mathrm{RBx} 14255$ was similar to telithromycin except in human where RBx14255 showed high metabolic stability compared to moderate stability in telithromycin. Similar in vitro/in vivo clearance data in mouse suggests the clearance of both the compound is likely through hepatic microsomal enzymes whereas, higher in vivo clearance in rat and dog suggests involvement of non-microsomal enzymes as well.
The high oral bioavailability of RBx14255 in rodents and non-rodent compared to moderate bioavailability in telithromycin is consistent with the intestinal efflux values which is $44 \%$ lower than telithromycin. The moderate permeability of RBx14255 along with low intestinal efflux ratio overrides its low aqueous solubility and enables high oral bioavailability in rodents and non-rodents compared to telithromycin.

RBx14255 did not inhibit CYPs 1A2, 2C9, 2C19 and 2D6 in vitro and is unlikely to cause drug-drug interactions mediated by these isozymes. However, inhibition of CYP3A4 by RBx14255 is likely to cause drug-drug interaction with drugs metabolized through CYP3A4. The overall risk-profile for CYPmediated drug-drug interactions is similar to telithromycin and therefore appears acceptable.

The pharmacokinetic properties of RBx14255 in the preclinical species suggest that it has the potential to be administered as relative low dose BID dose. One of the reasons for the high volume of distribution in all preclinical species is likely due to high distribution in lungs as observed in rat. Its moderately long half-life in vivo in the various animal species $\left(\mathrm{t}^{1} / 2=1.57 \mathrm{~h}\right.$ in the mouse, $2.63 \mathrm{~h}$ in rat and $17 \mathrm{~h}$ in dog), result from a combination of a relatively low clearance and a high volume of distribution. Allometric scaling of the preclinical pharmacokinetic data predicts moderate half-life of about $9.5 \mathrm{~h}$ in humans suggests a BID dose for clinical efficacy. The high volume of distribution predicted in human is likely to show clinical relevance in lung distribution of RBx14255 as observed in rodents and non-rodents. The predicted human efficacious dose range of 124-226 mg for $\mathrm{RBx} 14255$ makes it amenable to further oral dosage form study design in humans.

The efficacy of any drug is dependent upon its transport and penetration to the target site of infection. For drugs of the RTI pathogens, high bronchopulmonary concentrations can be a key predictor of clinical outcome. In all three pharmacodynamic animal models such as Swiss mice and Sprague Dawley rats RBx14255 displayed a potent antibacterial profile as compared to standard of care drugs. In $\mathrm{ED}_{50}$ model in Swiss mice RBx14255 showed better potency as compared to telithromycin, amoxicillin/clavulanic acid and clarithromycin. Against S. pneumoniae MA80, RBx14255 exhibited equipotent activity as compared to telithromycin at one fourth exposure levels in the plasma of Sprague Dawley rats 
indicating its superior in vivo potency. This better efficacy profile at lesser exposure levels may yield better therapeutic safety window. RBx14255 has also shown good efficacy in pulmonary infection induced by $H$. influenzae. RBx14255 showed bactericidal activity against $H$. influenzae. RBx14255 exhibited accumulation in lung tissue much above its MIC levels $(2 \mu \mathrm{g} / \mathrm{mL})$ up to $8 \mathrm{~h}$. The concentrations of RBx14255 in the lung tissue and epithelial lining fluid were more than the corresponding plasma levels at all time points. The pharmacodynamic parameter associated with bacterial inhibition correlated well with the achieved levels of RBx14255 in the epithelial lining fluid and lung tissue.

\section{ACKNOWLEDGMENTS}

\section{Conflict of interest statement}

The authors were the former employees of Ranbaxy Research Laboratories and Daiichi Sankyo India Pharma Private Limited, Gurgaon, India.

\section{REFERENCES}

1. Grief SN, Loza JK. Guidelines for the Evaluation and Treatment of Pneumonia. Prim Care, 2018; 45: 485503. doi: 10.1016/j.pop.2018.04.001.

2. Brown JS. Community-acquired pneumonia. Clinical Medicine, 2012; 12(6), 538-543. doi:10.7861/clinmedicine.12-6-538.

3. Lee KH, Gordon A, Foxman B. The role of respiratory viruses in the etiology of bacterHenriques-Normark B, Elaine I, Tuomanen EI. The Pneumococcus: Epidemiology, Microbiology, and Pathogenesis. Cold Spring Harb Perspect Med, 2013; 3(7). doi: 10.1101/cshperspect.a010215.

4. Henriques-Normark B, Elaine I, Tuomanen EI. The Pneumococcus: Epidemiology, Microbiology, and Pathogenesis. Cold Spring Harb Perspect Med, 2013; 3(7). doi: 10.1101/cshperspect.a010215.

5. Raj VS, Barman TK, Kalia V, Purnapatre K, Dube S, Ramkumar G, Bhateja P, Mathur T, Chaira T, Upadhyay DJ, Surase YB, Venkataramanan R, Chakrabarti A, Das B, Bhatnagar PK. A novel ketolide RBx14255 with activity against multi-drug 2 resistant Streptococcus pneumoniae. Antimicrob Agents Chemother, 2014; 58(8): 4283-89. doi:10.1128/AAC.01589-13.

6. Hoban DJ, Zhanel GG. Clinical implications of macrolide resistance in 348 community-acquired respiratory tract infections. Expert Rev Anti Infect
Ther, 2006; 349(4):973-80. doi: 10.1586/14757210.4.6.973.

7. Stacevičienè I, Petraitienè S, Vaičiūnienè D, Alasevičius T, Kirslienė J, Usonis V. Antibiotic resistance of Streptococcus pneumoniae, isolated from nasopharynx of preschool children with acute respiratory tract infection in Lithuania. BMC Infect Dis, 2016; 16:216. doi: 10.1186/s12879-016-1544-9.

8. Zhanel GG, Wierzbowski AK, Hisanaga T, Hoban DJ. The use of ketolides in treatment of upper respiratory tract infections. Curr Infect Dis Rep, 2004;6(3): 191-99. doi:10.1007/s11908-004-0008-3

9. Weiser JN, Ferreira DM, Paton JC. Streptococcus pneumoniae: transmission, colonization and invasion. Nat Rev Microbiol, 2018; 16:355-67. doi: 10.1038/s41579-018-0001-8.

10. Slack MP. A review of the role of Haemophilus influenzae in community-acquired pneumonia. Pneumonia, 2015; 6: 26-43. doi:10.15172/pneu.2015.6/520.

11. Wang S, Tafalla M, Hanssens L, Dolhain J. A review of Haemophilus influenzae disease in Europe from 2000-2014: challenges, successes and the contribution of hexavalent combination vaccines. Expert Rev Vaccines, 2017; 16: 1095-1105. doi: 10.1080/14760584.2017.1383157.

12. Fernandes P, Martens E, Pereira D. Nature nurtures the design of new semi-synthetic macrolide antibiotics. J Antibiot, 2017; 70: 527-33. doi: 10.1038/ja.2016.137.

13. Ross DB. The FDA and the case of Ketek. N Engl J Med, 2007;356: 1601-04. doi: 10.1056/NEJMp078032.

14. FDA, 2007. Telithromycin (marketed as Ketek) Information.

http://www.fda.gov/drugs/drugsafety/postmarketdru gsafetyinformationforpatientsandproviders/ucm 1078 24.htm.

15. Jarvis LM. The Ketek effect. Chem Eng New, 2008; 86:861-62.

16. Bertrand D, Bertrand S, Neveu E, Fernandes P. Molecular characterization of off-target activities of telithromycin: a potential role or nicotinic acetylcholine receptors. Antimicrob. Agents Chemother, 2010; 54: 5399-402. doi: 10.1128/AAC.00840-10.

17. Nicole W, Anthony MS, Donald EL, Keith PK. High-level telithromycin resistance in a clinical isolate of Streptococcus pneumoniae. Antimicrob Agents Chemother, 2007; 51: 1092-95. doi:10.1128/AAC.01153-06.

18. Hirakata Y. The first telithromycin-resistant Streptococcus pneumoniae isolate in Japan associated with erm(B) and mutations in $23 \mathrm{~S}$ rRNA and riboprotein L4. Jpn J Infect Dis, 2007; 60: 48-50.

19. Llano-Sotelo B, Dunkle J, Klepacki D, Zhang W, Fernandes P, Cate JH, Mankin AS. Binding and 
action of CEM-101, a new fluoroketolide antibiotic that inhibits protein synthesis. Antimicrob Agents Chemother, 2010; 54:4961-70. doi: 10.1128/AAC.00860-10.

20. Farrell DJ, Sader HS, Castanheira M, Biedenbach DJ, Rhomberg PR, Jones RN. Antimicrobial characterisation of CEM-101 activity against respiratory tract pathogens, including multidrugresistant pneumococcal serogroup 19A isolates. Int J Antimicrob Agents, 2010; 35: 537-43. doi: 10.1016/j.bmcl.2011.10.101

21. Kumar R, Rathy S, Hajare AK, Surase YB, Dullu J, Jadhav JS, Venkataramanan R, Chakrabarti A, Pandya M, Bhateja P, Ramkumar G, Das B. Synthesis and antibacterial activity of a novel series of acylides active against community acquired respiratory pathogens. Bioorg Med Chem Lett, 2012; 22: 476-81. doi: 10.1016/j.bmcl.2011.10.101.

22. Nam G, Kim YS, Choi KI. Synthesis and antibacterial activity of new 9-O-arylpropenyloxime ketolides. Bioorg Med Chem Lett, 2010; 20:267174.

23. Oldach D, Clark K, Schranz J, Das A, Craft JC, Scott D, Jamieson BD, Fernandes P. Randomized, doubleblind, multicenter phase 2 study comparing the efficacy and safety of oral solithromycin (CEM-101) to those of oral levofloxacin in the treatment of patients with community-acquired bacterial pneumonia. Antimicrob Agents Chemother, 2013; 57: 2526-34. doi: 10.1128/AAC.00197-13.

24. Chaturvedi PR, Decker CJ, Odinecs A. Prediction of pharmacokinetic properties using experimental approaches during early drug discovery. Curr Opin Chem Biol, 2001; 5: 452-60. doi: 10.1016/s13675931(00)00228-3.

25. Mehmood I, Balian JD. Interspecies scaling: predicting clearance of drugs in humans: three different approaches. Xenobiotica,1996; 26: 887-95. doi: 10.3109/00498259609052491.

26. Boxenbaum H, Ronfeld R. Interspecies pharmacokinetic scaling and the Dedrick plots. Am J Physiol, 1983; 245(6):R768-75. doi: 10.1152/ajpregu.1983.245.6.R768.

27. Mahmood I, Yuan R. A comparative study of allometric scaling with plasma concentrations predicted by species-invariant time methods. Biopharm Drug Dispos, 1999; 20(3):37-144. doi: 10.1002/(sici)1099-081x(199904)20:3<137::aidbdd165>3.0.co;2-i.

28. Puech C, Hodin S, Forest V, He Z, Mismetti P, Delavenne X, Perek N. Assessment of HBEC-5i endothelial cell line cultivated in astrocyte conditioned medium as a human blood-brain barrier model for $\mathrm{ABC}$ drug transport studies. Int J Pharm, Elsevier, 2018; $551 \quad$ (1-2): 281 289. doi:10.1016/j.ijpharm.2018.09.040
29. Mahmood I. Allometric Issues in Drug Development. J Pharm Sci, 1999; 88(11): 1101-6. doi:10.1021/js9902163.

30. Mahmood I. Application of allometric principles for the prediction of pharmacokinetics in human and veterinary drug development. Adv Drug Deliv Rev, 2007; 59: 1177-92. doi: 10.1016/j.addr.2007.05.015.

31. Stets R, Monica P, Joven RG, Ismail M, William N, Andrzej M, Courtney K, Anita FD, Lynne GR, Judith NS, Amy M, Paul BE, Evan T, Paul CM, Evan L. Omadacycline for Community-Acquired Bacterial Pneumonia. N Engl J Med, 2019; 380(6): 517-27. doi: 10.1056/NEJMoa1800201.

32. Kalil AC, Metersky ML, Klompas M, Muscedere J, Sweeney DA, Palmer LB, Napolitano LM, O'Grady NP, Bartlett JG, Carratalà J, El Solh AA, Ewig S, Fey PD, File TM Jr, Restrepo MI15, Roberts JA, Waterer GW, Cruse P Knight SL8, Brozek JL. Management of Adults with Hospital-acquired and Ventilator-associated Pneumonia: 2016 Clinical Practice Guidelines by the Infectious Diseases Society of America and the American Thoracic Society. Clin Infect Dis, 2016; 63(5): 575-82. doi: 10.1093/cid/ciw353.

33. Welte T, Torres A, Nathwani D. Clinical and economic burden of community acquired pneumonia among adults in Europe. Thorax, 2012; 67: 71-9. doi: 10.1136/thx.2009.129502.

34. File TM Jr., Marrie TJ. Burden of communityacquired pneumonia in North American adults. Postgrad Med, 2012; 122: 130-41. doi: 10.3810/pgm.2010.03.2130.

35. World Health Organization, 2017. Global priority list of antibiotic-resistant bacteria to guide research, discovery, and development of new antibiotics. (http:// apps .who .int/ medicinedocs/ documents/ s23171en/ s23171en .pdf).

36. Kollef MH, Betthauser KD. New antibiotics for community-acquired pneumonia. Curr Opin Infect Dis, 2019; 31: 1-6. doi: 10.1097/QCO.0000000000000526.

37. Kumar M, Mathur T, Barman TK, Ramkumar G, Bhati A, Shukla G, Kalia V, Pandya M, Raj VS, Upadhyay DJ, Vaishnavi C, Chakrabarti A, Das $\mathrm{B}$, Bhatnagar PK. In vitro and in vivo activities of the novel ketolide RBx14255 against Clostridium difficile. Antimicrob Agents Chemother., 2012; 56: 5986-89. doi: 10.1128/AAC.00015-12.

38. Barman TK, Kumar M, Chaira T, Gangadharan R, Singhal S, Rao M, Mathur T, Bhateja P, Pandya M, Ramadass V, Chakrabarti A, Das B, Upadhyay DJ, Raj VS. Potential of a fluoroketolide RBx14255 against Streptococcus pneumoniae, Neisseria meningitidis and Haemophilus influenzae in experimental murine meningitis model. J Antimicrob Chemother, 2019; 74(7):1962-70. doi: 10.1093/jac/dkz119. 